\title{
INTERNALIZATION OF RELIGIOUS VALUES BASED PESANTREN (Study of SMA Muhammadiyah 01 Metro Lampung)
}

\author{
Maragustam \\ Universitas Islam Negeri Sunan Kalijaga \\ Caturtunggal, Depok, Sleman, Yogyakarta 55281 \\ E-mail:maragustam@uin-suka.ac.id \\ Yogi Wibisono \\ Universitas Islam Negeri Sunan Kalijaga \\ Caturtunggal, Depok, Sleman, Yogyakarta 55281 \\ E-mail:yogiwibisono94@gmail.com
}

\begin{tabular}{c|c|c}
\hline Received: & Revised: & Approved: \\
12/07/2020 & $07 / 12 / 2020$ & $14 / 12 / 2020$ \\
\hline
\end{tabular}

DOI: https:/ / doi.org/10.32332/akademika.v25i2. 2272

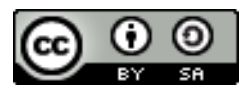

Internalization Of Religious Values Based Pesantren (Study Of SMA Muhammadiyah 01 Metro Lampung) Licensed Under a Creative Commons Attribution-ShareAlike 4.0 Internasional License

\begin{abstract}
Action or morality in principle begins with a deep value in the soul. That deep value becomes a pattern of belief, awareness, and thought. Because that value has become a mindset, taste, and belief, one will easily do positive and negative actions. So, the planting of value becomes a necessity in education. This research will answer how the school's strategy instills religious values, what religious values are instilled, its supporters and inhibitions, and how they result. This type of research is qualitative with a pedagogical approach. Determination of subjects using purposive and Snowball. Data collection with observations, interviews, and documentation. The analysis technique uses Miles and Huberman models. The conclusion is (1) strategies for planting religious values are habituation, teaching the values of goodness, nudity, repentance with istighatsah, and punishment; (2) The religious values instilled are personal and social worship; (3) the less successful factors of planting religious values are less
\end{abstract}


aware learners, teachers have difficulty supervising students, parents are less exemplary, and socio-cultural environments are less supportive. Simultaneously, the success factor is compact managers, adequate facilities and infrastructure, strict school discipline application, passionate teachers, sincere, and professional managers applying the pesantren system.

Keywords: Planting, religious values, and pesantren

\section{A. Introduction}

The current globalization brings positive and negative influences in the cultivation of religious values. The positive impacts include making it easier to plant value. While the adverse effects, among others, learners readily absorb the negative values because sinners wrap the negative values wrapped in such away. Consciously or unconsciously makes learners discard the nation's religious and noble spiritual values and replace them with pragmatic, materialist, and hedonistic values. Furthermore, learners make religious values only for the hereafter. In other words, there is no connection between religion and the world. Therefore, some people move away from the spiritual, socio-cultural, and philosophical values of their people. In this position, liberalism, materialism, hedonism, and secularism control human life. Man becomes out of character, i.e., unable to distinguish which is real and not, which is the nature of need and want.

The other result is that someone becomes a split personality (a complicated psychological condition and the sufferer has a double personality), has no living grip, and even loses his or her identity. For example, a class XI student hit his teacher in art subjects to die. It happened because the teacher rebuked the student not to disturb her friend in the lesson hours were in progress. The incident occurred at SMAN 1 Torjun Sampang Madura, East Java. ${ }^{1}$ In February 2020, in Malang, a junior high school student in Malang, MS (13), was forced to undergo amputation surgery on the middle finger of his right hand after allegedly being the victim of bully seven schoolmates. ${ }^{2}$

${ }^{1}$ Hendra Gunawan, “Kronologis Pemukulan Guru Oleh Siswa, Sesampai Di Rumah Ahmad Budi Cahyono Pusing Lalu Tewas," 2018, https:/ / www.tribunnews.com/regional/2018/02/03/kronologis-pemukulanguru-oleh-siswa-sesampai-di-rumah-ahmad-budi-cahyono-pusing-lalu-tewas.

${ }^{2}$ Michhael Hangga Wismabrata, “Marak Kasus 'Bullying' Di Sekolah, Ada Yang Hilang Dalam Diri Pelaku," 2020, https:/ / regional.kompas.com/read/2020/02/14/05150001/marak-kasusbullying-di-sekolah-ada-yang-hilang-dalam-diri-pelaku?page=all. 
Based on police data in Bantul Regency, during the 2009-2010 period, 45 students were involved in criminal cases in the form of theft, escape the underage girl and persecution. Besides, there are also cases of student drug users. 2009-May 2010 found nine instances of drug users conducted by students. ${ }^{3}$

Man best in an Islamic perspective realizes the essence of his existence as an individual creature, a social creature, and a creature of God. It means that people who can optimize their potential in the form of development of reason, feeling, spiritual-belief, and attitude optimally to perform its duties as Individual, social, and Servant of God in the Religious frame values. Thus it is indeed a human being, not a righteous enough individual, but must also be socially moral. That is the character that the Prophet SAW to his people based on religious values to peace for the whole universe (QS. Al-Anbiya: 107).

Education is social engineering in a society that aims to instill a particular value. Besides, education is forming human beings to have his humanitarian (anthropocentric) level and its level of Divinity (Thecentric). Godhead and humanity are integral to life (QS. Ali Imron: 112). Planting value in education varies greatly depending on the institution that devised any amount that would like to be attributed. Because the school has its vision and mission that want to be achieved, then positively every institution, including SMA Muhammadiyah 1 Metro Lampung, has a specific strategy in the certification of grades to the participants. In education, every strategy and method is perfect for all subject matters. Because the approach is very dependent on the material, learning objectives, and the situation that surrounds it, and the vision of the mission carried by the institution concerned.

To build intelligent and religious human beings, SMA Muhammadiyah 1 Metro has been implementing a boarding school that adopted the Pesantren system-acknowledged that the boarding system is advantageous in the formation of characters, especially religious character. According to M. Nuh (as Minister of National Education) in Republika online, quoted by Maragustam, it is explained that pesantren tradition is significant in school. The point is the habituation of positive values into positive traditions, which become strong positive character carvings. ${ }^{4}$

\footnotetext{
${ }^{3}$ Titik Sunarti Widyaningsih, Zamroni, and Darmiyati Zuchdi, “Internalisasi Dan Aktualisasi Nilai-Nilai Karakter Pada Siswa Smp Dalam Perspektif Fenomenologis," Jurnal Pembangunan Pendidikan: Fondasi Dan Aplikasi 2, no. 2 (December 1, 2014): 182, https://doi.org/10.21831/jppfa.v2i2.2658.

4 Maragustam, Filsafat Pendidikan Islam Menuju Pembentukan Karakter (Yogyakarta: FITK UIN Sunan Kalijaga, 2020), 287.
} 
According to Gordon Allport, value is a belief that makes a person act on their chosen basis. ${ }^{5}$ Rifa'i, in his research, shows that religious values will be able to make learners more tolerant and more ethical, even practicing his spiritual teachings and touching their affection and psychomotor. $^{6}$ In this regard, Allport emphasizes value on the psychological aspect of belief, which is higher than other elements such as desire, motive, attitude, desires, and needs. Faith is in the realm of religion. So that religious values are the highest level in human psychology, which makeup in attitudes and behavior and bring two consequences and the world and the hereafter. Max Scheler creates a hierarchy of values into four; ranging from the lowest to the highest level, namely: Unpleasant values (related to the senses) Vital values Spiritual values are further divided into three kinds, namely aesthetic values, values are completely wrong, and pure knowledge of religious values. ${ }^{7}$

Religion is a belief system that governs God's faith and worship and the rules relating to the Association of Man and physical, psychological, and social-cultural environments. In a dictionary of psychology, eligibility means involvement, interest, or participation in religion. Although several authors use the term to refer to the high level of a person's religious commitment, it is precisely referring to sustainability participation in rituals and ethical practices to be judged Low or moderate reliability. ${ }^{8}$

Religion is the highest value of spirituality, absolute and eternal, and is sourced from human beliefs and beliefs. This is by the opinion of Said Agil that in the context of educational ethics in Islam, the most useful and powerful sources of ethics and values are the Qur'an and sunnah of the Prophet SAW, which was later developed by the results of ijtihad scholars. Values derived from customs and ideology are very vulnerable and situational. Because both are products of human culture that is relative, sometimes local and situational. At the same time, the values of the Qur'an

${ }^{5}$ Rohmat Mulyana, Mengartikulasikan Pendidikan Nilai, Cet. Ke-2 (Bandung: Alfabeta, 2011), 9.

Muh Khoirul Rifa'i, “Internalisasi Nilai-Nilai Religius Berbasis Multikultural Dalam Membentuk Insan Kamil," Jurnal Pendidikan Agama Islam (Journal of Islamic Education Studies) 4, no. 1 (May 2, 2016): 131, https://doi.org/10.15642/jpai.2016.4.1.116-133.

7 J. Sudarminta, Etika Umum: Kajian Tentang Beberapa Masalah Pokok Dan Teori Etika Normatif, Cet. ke-3 (Yogyakarta: Kanisius, 2013), 152.

${ }^{8}$ Athur S Reber Reber and Emily S Reber, Kamus Psikologi, Terj. Yudi Santoso, Cet. I (Yogyakarta: Pustaka Pelajar, 2010), 822. 
are healthy because the teachings in it are absolute and universal. ${ }^{9}$

Religious is an adjective from religious (English) "connected with religion or a particular religion." Glock and Stark state that religion is a religion-related belief, which can be seen through the individual's activity or behavior concerned with the faith and beliefs in question. Religion is not a single thing but is a system consisting of several aspects. The psychology of religion is known as cooperation consciousness, religious (religious consciousness), and spiritual experiences (religious experience). Meanwhile, according to Stark and Glock, the abundance can be classified into five dimensions, i.e., the belief dimension, religious practice dimension, the experience dimension, knowledge, and the consequences dimension. ${ }^{10}$

Religious attitudes can be interpreted as a process to the power of Ruhaniyah that becomes a motor drive to direct human behavior in daily life consists of feelings, thoughts, wishful thinking to carry out the trust God with his recommendation, and obligations relating to his religion. Religion is to live the teachings of faith thoroughly, and the most fundamental thing is to make religion the foundation of Education. According to Diane Tilman, there are twelve central values of character that need to be attributed, namely (1) peace, (2) appreciation, (3) love, (4) tolerance, (5) honesty, (6) humility, (7) cooperation, (8) happiness, (9) responsibilities, (10) simplicity, (11) freedom, and (12) unity. ${ }^{11}$

Meanwhile, according to Thomas Lickona, he offered two dominant values based on moral law, the attitude of respect and responsibility. These values represent the primary basis of universal morality. The two central values are indispensable for (1) Healthy development of self (Soul), (2) caring for Interpersonal relationships, (3) A Humanist and democratic society, and (3) a fair and peaceful world. 12

Meanwhile, according to Fathurrahman religious values are divided into 5, namely the value of worship, purest jihad, morality and discipline,

${ }^{9}$ Said Agil Husen Al Munawwar, Aktualisasi Nilai-Nilai Qur'ani Dalam Sistem Pendidikan Islam (Jakarata: Ciputat Press, 2005), 3.

${ }^{10}$ Rodney Starck and Charles Y Glock, American Piety: The Nature of Religious Commitment, Vol.I (Berkeley Los Angeles: University of California Press, 1968), 14.

${ }^{11}$ Diane Tilman, Living Values Activities for Young Adults (Jakarta: Grasindo, 2004), 7 .

12 Thomas Lichona, Educating for Character. How Our School Can Teach Respect and Responsibility (Jakarta: Bumi Aksara, 2013), 69-70. 
transparency, and trust and control values. ${ }^{13}$ The value of worship is God's obedience to God implemented in daily activities such as prayer, fasting, zakat, and others. Worship is the consequence and implication of the faith of Allah SWT. The Ruhul Jihad is the soul that encourages people to work or struggle in earnest. It is the underlying purpose of human life, namely hablumminallah, hamblumminnas, and hamblum minal alam. With the commitment of the purest jihad, then man actualized himself and did work always based on the attitude of struggle and endeavor sincerely. Moral value is a form of the Jama ' of Khuluq, meaning temper, habit, shyness, and customs.

While discipline is manifesting inhabit when performing daily routine worship. When a man shows his religion promptly, then the value of discipline is automatically embedded in the person. The amount of transparency is crucial in education and learning. Should all students ' environment, especially the school environment, should be an example for them. The values of Amanah are etymological, trustworthy, and responsible. In the context of education, all educational institutions must hold the importance of trust, while sincere is a person who is clean or missing a sense of the selfless of everything he does. His uncle was only for God alone.

The strategy is a planned pattern and set intentionally to perform activities or actions. ${ }^{14}$ According to J. R David, strategy in education is defined as planning that contains a series of activities designed to achieve specific educational objectives. ${ }^{15}$ The knowledge of value is a passion for doctrine or value, so it is the belief and awareness of the truth of doctrine or value embodied in attitudes and behavior. ${ }^{16}$ Thus the value-saving strategy is essentially still conceptual about the decision to be taken in a lesson. Therefore, to implement the strategy is adjusted to a specific method to facilitate the implementation.

Maragustam argues that if the character whose contents are values is $100 \%$ hereditary or congenital since birth, then the character can not be formed. However, if heredity is only one factor of the character, it can be

${ }^{13}$ Faturrohman, Budaya Religius Dalam Peningkatan Mutu Pendidikan, Tinjauan Teoritik Dan Praktik Konstekstualisasi Pendidikan Agama Di Sekolah (Yogyakarta: Kalimemedia, 2015), 60-69.

14 Abdul Majid, Strategi Pembelajaran (Bandung: PT. Remaja Rosdakarya, 2013), 4 .

${ }^{15}$ Ahmad Tafsir, Ilmu Pendidikan Islam (Bandung: Remaja Rosdakarya, 2004), 8.

16 Pusat Bahasa Depdiknas, Kamus Besar Bahasa Indonesia (Jakarta: Balai Pustaka, 2003), 439. 
established from an early age in the womb. There are five pillars of valuegiving strategy in character building, including religious characters (1) Moral Acting (good deeds) by habituation and cultured (2) to teach ethical values (moral knowing), (3) moral feeling and loving (feeling and loving the good), (4) the moral modeling of the surrounding environment, and (5) The penance of all sins (non-academic penance) and unusable things (academic penance) even though fiqh is permissible. 17

The approach used is pedagogic. This research is a type of field and qualitative research. Determination of subjects using purposive and Snowball. With purposive and Snowball devices, the study subjects were the head of the dormitory, the principal, the teachers, and the learners. Data collection uses participatory observations, in-depth interviews, and documentation. The analysis technique uses miles and Huberman models with steps; data collection, data reduction, data presentation, and data verification/collection. The validity of the data uses source triangulation and techniques.

SMA Muhammadiyah 01 Metro Lampung is the first school in the Metro that established the boarding school system in 2015 by adopting the Pesantren system. This system is used for the security of religious values. The boarding school was made as transferring media (rather than value, science, and culture) and transformative (planting and forming religious values to learners to become their personality). Students in this institution are all Muslim. Therefore, this institute makes the program of planting religious values as a basis in being and behave to be not easily affected by the culture, or global flows are negative. So their lives are framed by their religious values. In other words, in the face of negative impacts, the student's global flow can make religious values as its filters.

\section{B. Implementation of the planting of religious values to learners}

Implementation of the planting of religious values to learners based on the research results that religious activities in the planting of religious values in this institute largely adopted the planting strategies of values that exist in Boarding. According to the principal and Islamic religious teachers that education in Pesantren is believed to be helpful and facilitate the process of cultivation of religious values in students. Among the activities of system pesantren that is adopted by the school is the Tadarus Al-Qur'an, prayers Dhuha, prayer berjam'ah Five-time, Friday prayers in schools, fasting circumcision, berinfaq, praying, friendly (smile and Greetings) to

${ }^{17}$ Maragustam, Filsafat Pendidikan Islam Menuju Pembentukan Karakter, 28589. 
others, study The books of Hadis, Tausyiah, and Istighatsah.

1. Sorogan strategy in planting religious values in the activities of the Koran and its memorization

Strategy Sorogan in planting religious values in the activities of the Qur'an and memorization every day except holidays, students enter school at 07:00. Before the lesson began held the Koran Tadarus. Before Tadarus begins with the advice of teachers on ethics and religious values when dealing with the Koran, keep manners, morality, understand the values that are read, and practice them in everyday life. Then the Qur'an was held by reading Al-Fatihah and continued with the Qur'an Tadarus. Then students deposit their memorization to Ustadz. In the implementation of this activity, all teachers or school residents also give an example directly to the students by maintaining the attitude and behavior when the activities of the Qur'an are ongoing.

The activity of "memorization" is known as the Sorogan method in Pesantren. A student is obliged to deposit one day before Kyai or Ustadz. In a language, Sorogan is derived from the Javanese word sorog, which means thrusting. In terms of the Sorogan method is the teacher or Kiai usually sit on a chair or prayer mat and a few volumes of books on the side as needed. Meanwhile, his disciples sat around him. There are vertices, some of which are wheeled chin, even one who has a half lying down, and some listen while looking at the scriptures that his teacher read. With this method, the students can encourage the material they want to learn to get guidance individually. In the past, in the Langgar-Langgar or Surau or mashallah, a Kiai would read the Quran verses first, then the student followed and put it down repeatedly.

Using a Sorogan strategy, every student or student will have the opportunity to learn directly with the teacher, Ustaz, or Kiai, who are experts in the memorization of the Qur'an. With this strategy, the teacher can guide, supervise, and assess the skills and attitudes of the learners directly. This strategy is advantageous in encouraging the improvement of moral quality and the ability of the students.

2. Using habituation strategies

Planting religious values, such as values of worship, silaturrahim, social care, responsibilities and trusts, and the value of the unity of Muslims through the strategic of the activities of praying Dhuha and praying in congregation both time and prayer Friday in School mosque, social duty, fasting Sunnah, Istighatsah, to be an administrator of the school organization, follow the BBQ (read Qur'an), and listen to the recitation of the Quran in general. 
Before the rest hours, learners are given 15 minutes to pray, Dhuha. Then after the arrival of Dhuhr, the students are obliged and used to follow the prayers of the congregation in the mosque and listen to Tausyiah $b a^{\prime} d a$ prayers of Dhuhr. Familiarize yourself with the study of hadith books, Baksos (social duty) every year, and hold trust and responsibility. It is also a habit to "become an organizational manager and in every event or event" the school does.

In addition to the habituation of these things, also familiarize each student should be friendly (smile, greet, and Greetings) to others both known and unknown, fasting Sunnah Monday and Thursday both students and teachers, caring for others by means of To people in need, and be used to follow the BBQ (read Qur'an) correctly and be used to follow istighatsah activities. Menurut Pierre Bourdieu in Maragustam that the habitus is a set of dispositions which incline agents to act and react in specific ways. The disposition generates practices and attitudes, which are "regular." The disposition which constitutes the habitus is inculcated, structured, durable, generative, and transposable-features that each deserves a brief explanation. Dispositions are acquired through a gradual process of inculcation in which early childhood experience is particularly important. Through a myriad of regular training and learning processes, such as those involved in the inculcation of tale manners (sit up straight, don't with your mouth full, etc.), the individual acquired set dispositions which mold the body and become second nature. The dispositions produced thereby are also structured because they unavoidably reflect the social conditions within which they were acquired. 18

The essence of the statement that Habitus is a set of dispositions (the efficiency) that conserves agents to act and to act in a certain way. Disposition produces the practice, perception, and attitude that "finally considered ordinary" unknowingly coordinated or controlled by the rules. The disposition that is habitus is firmly embedded, highly durable, generative, and transferable, such as children on the parent's way of eating (by sitting, standing, etc.) to the end of the child Obtain a permanent disposition that ends up being customary.

According to Ahmad Amin, a new habit can be a character if someone is happy or desires, something that is familiarity and acceptance of that desire, and repeated desires and acceptance are sufficient. ${ }^{19}$ In other words, new habits form good characters if they

\footnotetext{
${ }^{18}$ Maragustam, 114.

${ }^{19}$ Ahmad Amin, Al-Akhlaq (Jakarta: Bulan Bintang, 2010), 27.
} 
are self-trust (intrinsic motivation). According to Ibrahim Alfikiy, the habit is a thought that someone created in his mind, then connected with a feeling and repeated to reason to convince him as part of his behavior. ${ }^{20}$

The law of habituation through the six phases (1) thinks, (2) recording, (3) repetition, (4) storage, (5) repetition, and (6) habits..$^{21}$ With the habituation theory, the strategy done by this agency is appropriate and effective. Indeed, among the causes of the inability of a person's character even though he knows the goodness is because he is not trained (accustomed) to do that good. According to Syaibani that 99 percent of the deeds committed by humans is an automatic habit. ${ }^{22}$ Thus the habit is, in principle, a second character after the innate since birth.

3. Moral Knowing (teaching moral values of goodness) in the form of advice and study of the book

The strategy of advice in embedding religious values is applied intensively and sustainably. This strategy is used when the study activities, regularly scheduled and incidental. The study activities using this strategy of advice in the form of religious study of Maghrib $B a^{\prime} d a$ is Tausiyah, the study of the Riyadush Shalihin by Imam Nawawi, coaching with HPT material (Association of Decision Tarjih), ${ }^{23}$ and a scheduled force coaching. ${ }^{24}$

The advice given is religious values as the basis of understanding to make the student a religious character. In everyday life, This advice is always given by displaying a religious view of the values of which are good and evil. The advice given is derived from

${ }^{20}$ Ibrahim Elfiky, Terapi Beripikir Positif (Jakarta: Zaman, 2012), 90.

${ }^{21}$ Maragustam, Filsafat Pendidikan Islam Menuju Pembentukan Karakter, 115.

${ }^{22}$ Omar Mohammad Syaibani al, Falsafah Pendidikan Islam (Jakarta: Bulan Bintang, 2009), 156.

${ }^{23}$ HPT (Tarjih Verdict Association) is a book and is the highest intellectual product of the Tarjih Assembly. The Tarjih Assembly intensively poked the HPT in the Tarjih National Deliberation

${ }^{24}$ The development of the force is a routine activity carried out. This force's construction is carried out a day in 2 weeks, which coincides with Mari Sunday. The occupants of the dormitory do the coaching of each generation. 
the hadith studied in the book Riyadush Shalihin and coupled with the analysis of Ustadz.

Moral knowing according to Thomas Licona who quoted Maragustam there are six components of moral consciousness (sharpness captures which issues are good and which is not good any phenomenon that occurs), knowledge of moral values (ability Someone understands the various moral values), understands the point of view of others (the ability to accept other people's point of view, understand a situation and condition as others understand it, imaginative how others think, React, and are feeling), moral reasoning (understanding what it is immoral and why it should be immoral. In other words, and why should practice religious teachings, such as honest, responsible, socially caring, self-respecting and others, etc.), courage to make decisions (courage to make decisions among the options of various moral problems) and self-introduction (the ability to recognize our behavior, to evaluate it critically/honestly, and the ability to recognize the strengths and weaknesses that exist in the US and know the ways we take to maximize strength and reduce Such weaknesses). ${ }^{25}$ The planting of religious values is also in accordance with the opinion of Nurcholis Madjid, that religious atmosphere in the form of ritual and symbolic is regarded as "frame" or "skeleton"; therefore the Rite (religious activity) and formality is not the purpose, it will only have the meaning of the essence of the person who is concerned to the purpose of the essence, namely the closeness (Taqarrub) to God and goodness to fellow man (morality). ${ }^{26}$

4. Moral modeling strategy in instilling religious values

Throughout the school activities, especially the religious activities of the teacher, exemplify the students. Such as social activity, praying in the orphanage, Berinfaq in the orphanage or in the streets, discipline, etc. Everyone, including educators, is a model that seeks to present themselves as models or examples of living according to certain values and exemplary in the passion and practice of virtue values that will be attributed to learners. From the example, learners are expected to be impressed by the way educators live and ultimately strive for examples.

The example is important because every person, including learners, needs the transparency of the surrounding environment. People learn more and model from what he saw and experienced.

\footnotetext{
${ }^{25}$ Maragustam, Filsafat Pendidikan Islam Menuju Pembentukan Karakter, 145.

${ }^{26}$ Nurcholis Madjid, Masyarakat Religius (Jakarta: Paramadina, 1997), 128.
} 
Human learning devices are more effective in audio-visual. Human beings basically want to model. One of the essential meanings of the terms of Tarbiyah (education) is exemplary or imitation. The most influential example is the closest to oneself. As parents, teachers, relatives, community leaders, and anyone who is often associated with someone, especially his idol, it will be influential in character formation.

If the social environment is honest, trust, morality, courage, and refrain from acts contrary to the noble values of religion and nation, then a person close to him will take the example. Instead of someone, however big a business is being prepared for his goodness, no matter how holy he is, he will not be able to fulfill the principles of kindness, as long as he does not see his social environment as an example of moral values The high. It is very easy for someone to include parents, who teach children and students with good grades, but it is very difficult for them to perform when he sees the person who gave direction, and Guidance does not practice. Isn't the Lord saying in the Ash Shaff: 3: "There is great hatred on God's side that you say nothing you do." Once the influence of this transparency can be followed, a dialogue between the Prophet and his companions is called Handzalah. Handzalah, when with his family, felt a different feeling when with the prophet in terms of clarity, obedience, and fear of God, he saw that this was a form of hypocrisy. He went out on the road saying to himself: "Handzalah has made hypocrite!" Then he came to the prophet and explained what happened, what was felt from the difference of the spiritual situation between the family and with the prophet. Rasulullah SAW commented with his words: "If your stay is still like when with me, you will be inexperienced by the Angels in the streets, but $\mathrm{O}$ Handzalah ' moment and for a moment. That is why one of the successes of the Prophet in presenting his Islamic teachings is because he himself became the plenary of his people as such in the QS. Al-Ahazab: 21: Behold, the messenger of Allah, is a good example for you (i.e.) for the People who Hope (mercy) and the day of judgment, and he calls God.

5. The inclusion of religious values with a penance strategy in the activity of Istighotsah

The inclusion of religious values with a strategy in istighotsah activities. Istighotsah means a request or asks for help. Istighotsah is asking for help when things are complicated and painful. Istighatsah also found in the Qur'an. Al-Anfal: 9: "(Remember O Muhammad), when you ask for help (Istighotsah) to your lord, then he is permitted 
you:" Verily I will bring you reinforcements with a thousand angels come in succession. " (QS al-Anfal: 9). This verse described the events when the Prophet Muhammad asked for help from God. At that time, he was in the midst of the Battle of Badr War, which the enemy force was more excellent than doubling the greater of the Islamic forces. God granted Istighatsah Prophet SAW by assisting additional troops of a thousand troops Angel.

Among the negative influences of global currents is that people tend to be isolated, self-alienated, overflowing with pragmatic lives, materialists, and hedonists and further away from the all-God. Istighotsah presents as a way or medium to eliminate and/or minimize the negative traits. In the activity of Istighotsah contains various aspects of teaching such as prayers (please forgiveness), Shalawat, Tobat, ask God to Allah to avoid evil deeds, laugh (surrender) to Allah, please guide to Allah to remain in Islam, please peace, and others.

In the context of the life of the world as it is today, the existence of the Istighostah will be a part of positive energy in breaking down every problem of life that is in it and perceives the virtues of religious values (moral feeling). The Problem of human life lately that tends to ignore religious values, run away from the all-dimensional deity, will live again by joining the activities of Istighostah. Among the benefits of Istighatsah are:

1) As a prayer. Prayer is the submission of a servant to the creator.

2) Prayer in the joint is a very helpful mental enlightenment so that it can foster confidence in the face of heavy things.

3) Making a person is not easily discouraged if sometime later fails. If only making an effort alone, it is potentially a human that is easy to stress when failure.

4) God promises to grant every request of his servant as long as it is good for him.

5) God hates those who try to fulfill their lives with maximum effort but forget God's Prayer.

6) God hoped even to seek his servant, who prayed to him at certain times. ${ }^{27}$

According to Maragustam that in the Tobat, memory, thoughts, feelings, and conscience, in total, used to capture the meaning and

27 Ainani Zakiyatul Fuadah, "Peran Istighasah Dalam Mengurangi Kecemasan Siswa Menghadapi Ujian Nasional Di Uptd Sman I Mojo Kediri: Kajian Fenomenologis Psikosufistik Pendidikan Islam," Didaktika Religia 2, no. 2 (July 1, 2014): 125, https://doaj.org. 
value done so far, find a relationship with his God, and readiness to bear the consequences of the action Afterwards. The consequences of the penance will constitute an awareness of the nature and purpose of life, the value of virtue, bearing optimism, capturing the meaning of its various actions, the benefits and the void of its actions, and others in such a way, that one is brought forward To do an action in a new paradigm and new characters in the future. ${ }^{28}$

6. The planting of religious values with a penalty

The penalty here is the final effort in the cultivation of religious values. The sentence used is an educative punishment - moril, i.e., students who are sentenced not only to be aware of the logical relationship between mistakes and forms of punishment but have been feeling and or awakened the word heart, he feels to accept punishment as something that he experienced. Therefore, before the sentence is applied, school managers socialize all the rules, the teacher exemplified the rule, to teach students which values are good and which negative values in Religious perspectives, and the habituation of good things.

But there are also among the students who violate the rules. In this position, the educative-moral penalty is applied. The purpose of the sentence is for students to be conscious and aware of the wrongdoing and return to good things of religious value. The aim of punishment, according to Nata, is to cause the conversion to the students and give rise to the will not repeat the wrongs of right. ${ }^{29}$

\section{Results of the planting of religious values}

The results of planting religious values based on observations and interviews have successfully planted even the religious values are not yet entirely. This can be compared between inputs before the understanding of religious values before the boarding system and post-graduate boarding systems. This is by Fraenkel's opinion that value is very influential because it is a person's emotional grip. ${ }^{30}$

28 Maragustam, Pembentukan Karakter Anak Bangsa Perspektif Filsafat Pendidikan Islam (Yogyakarta: FITK UIN Sunan Kalijaga, 2019), 124-25.

${ }^{29}$ Abuddin Nata, Filsafat Pendidikan Islam, Cet I (Jakarta: Logos Wacana Ilmu, 1997), 104-5.

${ }^{30}$ Kokom Koomalasari and Didin Saripudin, Pendidikan Karakter Konsep Dan Aplikasi Living Values Eduacation (Bandung: PT Refika Aditama, 2017), 37. 


\begin{tabular}{|c|c|c|}
\hline $\begin{array}{l}\text { Aspects of religious } \\
\text { values both Mahdhoh } \\
\text { and Ghoiru Mahdhoh }\end{array}$ & $\begin{array}{l}\text { Before using } \\
\text { the boarding } \\
\text { system in the } \\
\text { planting of }\end{array}$ & $\begin{array}{l}\text { After the application of the } \\
\text { pesantren system in the planting } \\
\text { of religious values }\end{array}$ \\
\hline $\begin{array}{l}\text { The values of five } \\
\text { prayers }\end{array}$ & $\begin{array}{l}\text { The students } \\
\text { are indifferent } \\
\text { and laziness } \\
\text { and should be } \\
\text { on oprak-oprak } \\
\text { (telling the } \\
\text { crowd to } \\
\text { remind many } \\
\text { times) by the } \\
\text { father/Mother } \\
\text { teacher/Ustadz }\end{array}$ & $\begin{array}{l}\text { Most students perform five-time } \\
\text { prayers in a period without any } \\
\text { compulsion, self-willingness, no- } \\
\text { frills (reward), and no need to } \\
\text { oprak-oprak by the manager }\end{array}$ \\
\hline $\begin{array}{l}\text { The value of worship, } \\
\text { such as Dhuha, } \\
\text { Tahajjud, and Qabliyah } \\
\text { and Ba'diyah five } \\
\text { times }\end{array}$ & $\begin{array}{l}\text { Most students } \\
\text { do not }\end{array}$ & $\begin{array}{l}\text { Tell many people how to remind } \\
\text { repeatedly } \\
\text { Most students do so in order } \\
\text { without compulsion, self- } \\
\text { willingness, no-frills, and } \\
\text { unnecessarily on oprak-oprak } \\
\text { (Tell many people how to } \\
\text { remind repeatedly) by the } \\
\text { organizer }\end{array}$ \\
\hline $\begin{array}{l}\text { The value of fast } \\
\text { worship Monday and } \\
\text { Thursday }\end{array}$ & $\begin{array}{l}\text { Most students } \\
\text { do not }\end{array}$ & $\begin{array}{l}\text { Many students perform it } \\
\text { without compulsion, self- } \\
\text { willingness, no-frills, and } \\
\text { unnecessary oprak-oprak by the } \\
\text { organizer }\end{array}$ \\
\hline $\begin{array}{l}\text { The value of } \\
\text { Ramadan compulsory } \\
\text { fasting }\end{array}$ & $\begin{array}{l}\text { Most students } \\
\text { perform }\end{array}$ & $\begin{array}{l}\text { All students execute it without } \\
\text { compulsion, self-awareness, no- } \\
\text { frills, and unnecessary on oprak- } \\
\text { oprak by the organizer }\end{array}$ \\
\hline $\begin{array}{l}\text { The value of worship } \\
\text { is memorizing the } \\
\text { Koran and the Koran } \\
\text { Tadarus }\end{array}$ & $\begin{array}{l}\text { Almost all } \\
\text { students do not } \\
\text { memorize it }\end{array}$ & $\begin{array}{l}\text { All students implement it } \\
\text { according to the pace of each } \\
\text { student without compulsion, } \\
\text { self-willingness, no-frills } \\
\text { (reward), and not necessarily on } \\
\text { the oprak-oprak by the organizer }\end{array}$ \\
\hline
\end{tabular}




\begin{tabular}{|c|c|c|}
\hline $\begin{array}{l}\text { The value of social } \\
\text { worship in the form } \\
\text { of Infaq, social } \\
\text { service, and following } \\
\text { the commemoration } \\
\text { of Islamic days }\end{array}$ & $\begin{array}{l}\text { Most students } \\
\text { do not } \\
\text { implement } \\
\text { them }\end{array}$ & $\begin{array}{l}\text { Most students perform it } \\
\text { without coercion or with self- } \\
\text { awareness without compulsion, } \\
\text { self-willingness, no-frills } \\
\text { (reward), and not necessarily on } \\
\text { oprak-oprak by managers }\end{array}$ \\
\hline $\begin{array}{l}\text { Value of social } \\
\text { worship in the form } \\
\text { of trust and } \\
\text { responsibility of the } \\
\text { active organization }\end{array}$ & $\begin{array}{lr}\text { Almost } & \text { they } \\
\text { have } & \text { never } \\
\text { done it } & \end{array}$ & $\begin{array}{l}\text { Some of them have done it to } \\
\text { actively organized the trust and } \\
\text { responsible without compulsion, } \\
\text { self-willingness, no-frills } \\
\text { (reward), and not necessarily on } \\
\text { the oprak-oprak by the manager }\end{array}$ \\
\hline $\begin{array}{l}\text { Value Personal and } \\
\text { social worship in the } \\
\text { form of book study } \\
\text { and listen to } \\
\text { Taushiyah Ustadz }\end{array}$ & $\begin{array}{l}\text { Most students } \\
\text { do not pay } \\
\text { attention to it, } \\
\text { tend to be lazy, } \\
\text { sleepy, and feel } \\
\text { forced. }\end{array}$ & $\begin{array}{l}\text { Most notice, record, diligently, } \\
\text { and follow without resorting to }\end{array}$ \\
\hline $\begin{array}{l}\text { The value of personal } \\
\text { and social worship in } \\
\text { the form of prayer } \\
\text { and Istighasah }\end{array}$ & $\begin{array}{l}\text { Most students } \\
\text { do not pay } \\
\text { attention to it }\end{array}$ & $\begin{array}{l}\text { Most students pray and follow } \\
\text { dhikr together in the form of } \\
\text { istighatsah without compulsion, } \\
\text { sincerity, self-awareness, no- } \\
\text { frills (reward), and unnecessary } \\
\text { on oprak-oprak by the organizer }\end{array}$ \\
\hline $\begin{array}{l}\text { Value of social } \\
\text { worship in the form } \\
\text { of smiles, greeting, } \\
\text { and greetings }\end{array}$ & $\begin{array}{l}\text { Most students } \\
\text { don't do it }\end{array}$ & $\begin{array}{l}\text { Major students do it without } \\
\text { compulsion, self-awareness, no- } \\
\text { frills (rewarded), and not } \\
\text { necessarily on oprak-oprak by } \\
\text { managers }\end{array}$ \\
\hline $\begin{array}{l}\text { Value of personal and } \\
\text { social worship in the } \\
\text { form of disciplinary } \\
\text { value }\end{array}$ & $\begin{array}{l}\text { Most students } \\
\text { in religious } \\
\text { activities are } \\
\text { late, lazy and } \\
\text { forced to }\end{array}$ & $\begin{array}{l}\text { Most students are disciplined } \\
\text { and orderly without compulsion, } \\
\text { self-awareness, no-frills, and } \\
\text { unnecessary on Oprak-Oprak by } \\
\text { managers }\end{array}$ \\
\hline
\end{tabular}

In instilled values is a religion that is a multidimensional thing that includes cognitive, emotional, behavioral, and interpersonal. So the religion is divided into five aspects, namely ideological, intellectual, public practice, private practice, and religious experience, as it is discovered by 
Glock and Stack. 31

\section{Supporters and inhibitors in planting religious values}

Supporting and inhibiting in planting religious values in a process that is not undeniable that problems, constraints, advantages, advantages, and so forth become a powerful thing. This signifies that the process is actually happening and is carried out according to what was formulated from the beginning. In this case, in accordance with the opinion of Thoules Rebert. ${ }^{32}$ Based on the results of observations, interviews, and SWOT analysis-based (strengths-strengths, weaknesses-weaknesses, opportunities, and threatsthreats), the weaknesses and threats in the Religious values, among others: first, low student consciousness. It was seen as the manager oprak-oprak (telling the crowd to remind many times) to have them join the activity. Secondly, teacher difficulties in monitoring and supervision of students.

With the limitation of teachers and facilities such as CCTV, while many students with all their characteristics make the teacher difficult to supervise. Thirdly, parents do not give an example to their children in the practice of daily religious values. The religious values instilled in the school lacked the full support of his parents ' attitudes. Fourth, the socio-cultural environment in the community of each student is less conducive to connect the values instilled in the school. Not to mention the association of students both associating with humans and socializing with social media such as Handphone, the Internet, and others, making the values instilled in the school to be dispersed or blurred.

While the strengths and opportunities factor in the planting of religious values is the first, the solidarity of the managers with various methods of implementing religious values, secondly, the facilities and the Prasrana are adequate. Thirdly, there is an order of both the governance and order of the students. Fourth, the spirit, sincerity, and knowledge capability of the maintainers to implement the system of Pesantren.

\section{E. Conclusion}

The implementation of the planting of religious values in the participants implemented the boarding system with various strategies. Like habituation strategies, teaching values in a variety of activities, providing an example of all things, repentance through istighotsah activities, and the

${ }^{31}$ Michael J. Doane, "The Association between Religiosity and Subjective Well-Being: The Unique Contribution of Religious Service Attendance and the Mediating Role of Perceived Religious Social Support," The Irish Journal of Psychology 34, no. 1 (March 1, 2013): 49-66, https://doi.org/10.1080/03033910.2013.775071.

32 Robert H Thules, Pengantar Psikologi Agama (Jakarta: PT RajaGrafindo Persada, 2000), 119. 
granting of punishment as the end of another less successful strategy in Planting religious values.

The planting of religious values in the institution was successful. It can be proved by a significant change from the poor to be good and done consciously, freely, and understand the consequences of what is done. Being weaknesses and threats among the lack of student consciousness, teacher difficulties in monitoring and supervision of students, parents did not give an example to their children in the practice of religious values, and Socio-cultural Environment in the community of each student is less conducive to connect the values instilled in the school. While the strengths and opportunities of the managers ' solidarity with its various methods, adequate facilities and infrastructure, there is an order of both the governance of the management and the order of students, and the spirit, sincerity, and capability Knowledge of the maintainers to implement the system of Pesantren.

\section{REFERENCES}

Al Munawwar, Said Agil Husen. Aktualisasi Nilai-Nilai Qur'ani Dalam Sistem Pendidikan Islam. Jakarata: Ciputat Press, 2005.

Amin, Ahmad. Al-Akhlaq. Jakarta: Bulan Bintang, 2010.

Doane, Michael J. "The Association between Religiosity and Subjective Well-Being: The Unique Contribution of Religious Service Attendance and the Mediating Role of Perceived Religious Social Support." The Irish Journal of Psychology 34, no. 1 (March 1, 2013): 4966. https:/ / doi.org/10.1080/03033910.2013.775071.

Elfiky, Ibrahim. Terapi Beripikir Positif. Jakarta: Zaman, 2012.

Faturrohman. Budaya Religius Dalam Peningkatan Mutu Pendidikan, Tinjauan

Teoritik Dan Praktik Konstekstualisasi Pendidikan Agama Di Sekolah.

Yogyakarta: Kalimemedia, 2015.

Fuadah, Ainani Zakiyatul. "Peran Istighasah Dalam Mengurangi Kecemasan Siswa Menghadapi Ujian Nasional Di Uptd Sman I

Mojo Kediri: Kajian Fenomenologis Psikosufistik Pendidikan Islam." Didaktika Religia 2, no. 2 (July 1, 2014). https:/ / doaj.org.

Gunawan, Hendra. "Kronologis Pemukulan Guru Oleh Siswa, Sesampai Di

Rumah Ahmad Budi Cahyono Pusing Lalu Tewas." 2018. https://www.tribunnews.com/regional/2018/02/03/kronologispemukulan-guru-oleh-siswa-sesampai-di-rumah-ahmad-budicahyono-pusing-lalu-tewas.

Koomalasari, Kokom, and Didin Saripudin. Pendidikan Karakter Konsep Dan 
Aplikasi Living Values Eduacation. Bandung: PT Refika Aditama, 2017.

Lichona, Thomas. Educating for Character. How Our School Can Teach Respect and Responsibility. Jakarta: Bumi Aksara, 2013.

Madjid, Nurcholis. Masyarakat Religius. Jakarta: Paramadina, 1997.

Majid, Abdul. Strategi Pembelajaran. Bandung: PT. Remaja Rosdakarya, 2013.

Maragustam. Filsafat Pendidikan Islam Menuju Pembentukan Karakter. Yogyakarta: FITK UIN Sunan Kalijaga, 2020.

- - - . Pembentukan Karakter Anak Bangsa Perspektif Filsafat Pendidikan Islam. Yogyakarta: FITK UIN Sunan Kalijaga, 2019.

Mulyana, Rohmat. Mengartikulasikan Pendidikan Nilai. Ke-2. Bandung: Alfabeta, 2011.

Nata, Abuddin. Filsafat PendidikanIslam. Cet I. Jakarta: Logos Wacana Ilmu, 1997.

Pusat Bahasa Depdiknas. Kamus Besar Bahasa Indonesia. Jakarta: Balai Pustaka, 2003.

Reber, Athur S Reber, and Emily S Reber. Kamus Psikologi, Terj. Yudi Santoso. Cet. I. Yogyakarta: Pustaka Pelajar, 2010.

Rifa'i, Muh Khoirul. "INTERNALISASI NILAI-NILAI RELIGIUS BERBASIS MULTIKULTURAL DALAM MEMBENTUK INSAN KAMIL." Jurnal Pendidikan Agama Islam (Journal of Islamic Education Studies) 4, no. 1 (May 2, 2016): 116-33. https:// doi.org/10.15642/jpai.2016.4.1.116-133.

Starck, Rodney, and Charles Y Glock. American Piety: The Nature of Religious Commitment. Vol.I. Berkeley Los Angeles: University of California Press, 1968.

Sudarminta, J. Etika Umum: Kajian Tentang Beberapa Masalah Pokok Dan Teori Etika Normatif. Cet. ke-3. Yogyakarta: Kanisius, 2013.

Syaibani al, Omar Mohammad. Falsafah Pendidikan Islam. Jakarta: Bulan Bintang, 2009.

Tafsir, Ahmad. Ilmu Pendidikan Islam. Bandung: Remaja Rosdakarya, 2004.

Thules, Robert H. Pengantar Psikologi Agama. Jakarta: PT RajaGrafindo Persada, 2000.

Tilman, Diane. Living Values Activities for Young Adults. Jakarta: Grasindo, 2004.

Widyaningsih, Titik Sunarti, Zamroni Zamroni, and Darmiyati Zuchdi. "Internalisasi Dan Aktualisasi Nilai-Nilai Karakter Pada Siswa Smp Dalam Perspektif Fenomenologis." Jurnal Pembangunan Pendidikan: Fondasi Dan Aplikasi 2, no. 2 (December 1, 2014). https:// doi.org/10.21831/jppfa.v2i2.2658. 
352 AKADEMIKA: Jurnal Pemikiran Islam

, Vol. 25, No. 02 Juli - Desember 2020

Wismabrata, Michhael Hangga. “Marak Kasus 'Bullying' Di Sekolah, Ada Yang Hilang Dalam Diri Pelaku." 2020. https:/ / regional.kompas.com/read/2020/02/14/05150001/marakkasus-bullying-di-sekolah-ada-yang-hilang-dalam-diripelaku?page $=$ all. 